\title{
Generalizable principles for ecosystem stewardship-based management of social-ecological systems: lessons learned from Alaska
}

\author{
Winslow D. Hansen $^{1}$
}

\begin{abstract}
Human pressure could compromise the provision of ecosystem services if we do not implement strategies such as ecosystem stewardship to foster sustainable trajectories. Barriers to managing systems based on ecosystem stewardship principles are pervasive, including institutional constraints and uncertain system dynamics. However, solutions to help managers overcome these barriers are less common. How can we better integrate ecosystem stewardship into natural resource management practices? I draw on examples from the literature and two broadly applicable case studies from Alaska to suggest some generalizable principles that can help managers redirect how people use and view ecosystems. These include (1) accounting for both people and ecosystems in management actions; (2) considering historical and current system dynamics, but managing flexibly for the future; (3) identifying interactions between organizational, temporal, and spatial scales; (4) embracing multiple causes in addition to multiple objectives; and (5) acknowledging that there are no panaceas and that success will be incremental. I also identify next steps to rigorously evaluate the broad utility of these principles and quickly move principles from theory to application. The findings of this study suggest that natural resource managers are poised to overcome the barriers to implementing ecosystem stewardship and to develop innovative adaptations to socialecological problems.
\end{abstract}

Key Words: Alaska; bark beetle outbreak; ecosystem disservices; ecosystem services; ecosystem stewardship based management strategies; Kenai Peninsula; king salmon; regime shift; resilience; social-ecological systems; transformation; wildfire; Yukon River drainage

\section{INTRODUCTION}

People born 100 years from now are apt to have qualitatively different relationships with ecosystems if current trajectories of human-environment interaction persist (Rockström et al. 2009). Human use of ecosystems has led to accelerating rates of change (Vitousek et al. 1997, Foley et al. 2005, Barnosky et al. 2012) that increasingly threaten ecosystem services (Box 1; Daily et al. 1997), such as carbon sequestration, diminished soil fertility, and reduced availability of clean water and energy (Carpenter et al. 2009, Chapin 2009, Rockström et al. 2009). Loss of ecosystem services may compromise the resilience of social-ecological systems (SESs) and, thus, the economic, mental, and physical wellbeing of future generations (Mooney et al. 2009, Ehrlich et al. 2012). Here, I explore how natural resource managers could help redirect relationships between people and the environment toward sustainable outcomes, drawing on the literature and two broadly applicable case studies from Alaska: managing human-wildfire interactions on the Kenai Peninsula and the conservation of Yukon River king salmon (Oncorhynchus tshawytscha).

As resilience is compromised, SESs often respond nonlinearly, reaching critical thresholds at which regime shifts are triggered (Folke et al. 2009, Olsson et al. 2010). When regime shifts occur, systems swing to a profoundly different, and potentially unwanted, state that is then stabilized by different positive feedbacks (Scheffer et al. 2001, Biggs et al. 2009). Once stabilized, regime shifts are hard to reverse (Scheffer 2009). Strategies to foster resilience and redirect SESs toward trajectories of sustainable human-environment interaction are still in development. Resilience-based ecosystem stewardship (ES) is one promising approach (Chapin 2009, Walker et al. 2002). ES is a framework for holistically managing systems to sustain their longterm capacity to provide multiple ecosystem services that can support equitable human well-being under conditions of uncertainty and change (Chapin et al. 2010, 2011).

\section{Box 1. Glossary}

Ecosystem services: Benefits provided to people by ecosystems.

Ecosystem stewardship (ES): Holistic framework, based on proactively shaping change, that focuses on sustaining ecosystems to maintain their long-term capacity to provide services under social-ecological conditions of uncertainty and change.

Generalizable principle: Strategic element to help guide the effective implementation of a management strategy or approach.

Regime shift: Nonlinear, profound shifts in a system to a qualitatively different state that is difficult to reverse.

Resilience: Capacity of a system to tolerate disturbance without shifting to a qualitatively different state that is controlled by a different set of processes.

Social-ecological system (SES): A complex adaptive system, in which people rely on ecosystem services and are key drivers of ecosystems.

Sustainability: Using ecosystem services to meet the needs of people today without compromising the ability of future generations to meet their needs.

Natural resource managers often mediate interactions between people and the environment at local to regional scales. They may be a promising group to foster broader use of ES by implementing ES-based management strategies. Resource management paradigms increasingly value multiple ecosystem services (Chapin et al. 2010). However, strategies still often focus on meeting targets based on historical conditions (Chapin 2009, 2010). In a rapidly changing world, successfully implementing ES management will 
Fig. 1. Press-pulse dynamics conceptual framework (Collins et al. 2011), adapted to reflect context and scales of Alaskan case studies. In the framework, press- and pulse-ecosystem drivers shape ecosystem structure and function, which determine the quality and quantity of ecosystem services and disservices provisioned. Tradeoffs between services and disservices shape human wellbeing, which dictates environmental policy and natural resource management goals.

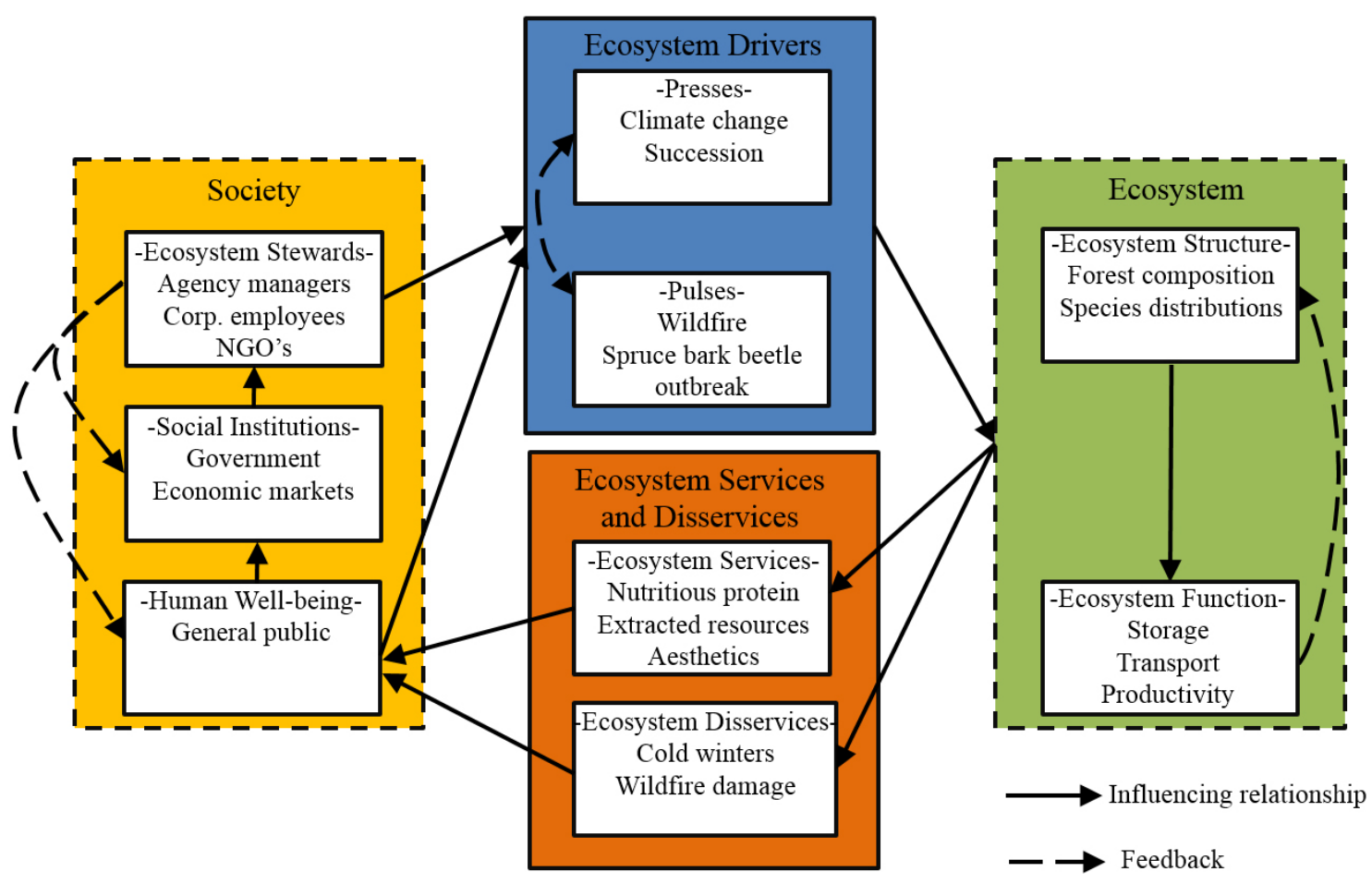

require shifting toward proactive governance that embraces and shapes change while also preparing for the unpredictable (Chapin et al. 2010). Numerous barriers to shifting toward ES management have been identified, such as system complexity, human agency, mismatches in social and ecological scales, differing human values, and power inequities (Walker et al. 2002, Chapin et al. 2006, Olsson et al. 2010, Cumming et al. 2013). Solutions and innovations are less common. Thus, developing new strategies and principles to help managers surmount current barriers is of critical importance.

How can we better integrate ES principles into current management practices? Building on the Ecological Society of America's Sustainable Biosphere Initiative (Lubchenco et al. 1991), principles of ES (Chapin et al. 2009a, 2010, 2011) and social-ecological transformation (Olsson et al. 2006, Olsson et al. 2008, Chapin et al. 2012), and the press-pulse dynamics conceptual framework (Collins et al. 2011), I conducted two case studies of natural resource management issues in Alaska to (1) identify current barriers to ES management and (2) suggest a set of generalizable principles, based on these case studies and supported by the literature, to help managers overcome barriers.

I focus on Alaskan case studies because climate change is magnified at high latitudes. Thus, northern systems may serve as environmental windows into the future for others (Serreze et al. 2000). Further, throughout Alaska and Canada, there is widespread recognition of the important connection between the environment and human well-being (Chapin et al. 2006, Kofinas et al. 2010, Brinkman et al. 2013, Hansen et al. 2013a). Agencies have a long history of experimenting with resource-management strategies (Ginter 1995, Kendrick 2003, Ruckelshaus et al. 2008, Armitage et al. 2011). However, many management issues in Alaska, particularly management of human-wildfire interactions and conservation of king salmon, are similar to pressing concerns in other locations, such as wildfire management in the Rocky Mountains and the numerous species for which conservation is a concern throughout the United States (Martinuzzi et al. 2013, Stephens et al. 2013).

\section{CONCEPTUAL FRAMEWORK}

The press-pulse dynamics conceptual framework is generalized and scalable. It is designed to flexibly foster integrated socialecological study of environmental change in a wide variety of contexts (Collins et al. 2011). I adapted the press-pulse framework to reflect characteristics and scales important in my case studies (Fig. 1; Ostrom et al. 2007, Ostrom and Cox 2010). Natural and human drivers of ecosystem structure and function are often characterized as presses or pulses (Folke et al. 2005, Ives and Carpenter 2007, Smith et al. 2009, Collins et al. 2011). Pressecosystem drivers cause incremental ecological change that adds up over time. Pulse-ecosystem drivers occur less frequently, suddenly, and often unpredictably. In interior Alaska, mean annual temperature, an important press, increased $3^{\circ} \mathrm{C}$ over the 
last 60 years (Chapin et al. 2014). As a result, wildfires, a key pulse in Alaska, have become more frequent and larger (Weber and Flannigan 1997, Flannigan et al. 2009, Kasischke et al. 2010). Interactions between these press- and pulse-ecosystem drivers may already be triggering regime shifts in Alaskan SESs, fundamentally altering postwildfire forest regeneration, species assemblages, and local food systems (Johnstone and Chapin 2006, Chapin et al. 2008, Johnstone et al. 2010, Kofinas et al. 2010, Mann et al. 2012).

Ecological change influences the provision of ecosystem services that support human well-being (Fig. 1; Daily et al. 1997, Millennium Ecosystem Assessment 2005). Many Alaskans rely on ecosystem services like fish and game for affordable protein, strongly contributing to food security and cultural identities (Loring and Gerlach 2009, 2010, McNeeley and Shulski 2011). Well-being, however, is often not determined just by ecosystem services. Trade-offs can sometimes occur between the benefits of services and costs of disservices (Hansen and Naughton 2013). Ecosystem disservices are consequences of ecological processes that detract from human well-being (Weitzman 1994, Mendelsohn and Olmstead 2009). Trade-offs between ecosystem services and disservices determine incentives and subsequently induce behaviors that shape people's relationship with the environment. Society has developed social institutions to manage such trade-offs (Beier et al. 2009, Trainor et al. 2009). These institutions create environmental policy that tries to minimize the costs of ecosystem disservices and ensure continued provision of ecosystem services. Managers are tasked with implementing those policies and must operate within the established bounds of the institution they are a part of.

\section{METHODS}

I applied the press-pulse dynamics conceptual framework to characterize two natural resource management issues in Alaska. These cases were chosen for their broad applicability to current management concerns across North America, as well as personal research experience in each case. For a detailed description of methods, see Brinkman et al. 2013, Hansen 2013, Hansen and Naughton 2013, and Hansen et al. 2013b. Both management of wildfire following bark-beetle outbreaks on the Kenai Peninsula and the conservation of Yukon River king salmon are prominent issues garnering regional, national, and international attention. As a result, there are several peer-reviewed publications and government reports on each case. In each case study, I triangulated among all available sources of information (Baumgärtner et al. 2008, Yin 2009), analyzing peer-reviewed papers, newspaper articles, government reports, and agency press releases. Many are cited in this paper. This information was used to identify the pressand pulse-ecosystem drivers in each case, their associated ecological effects, influences on ecosystem services, and subsequent management actions. I found no major inconsistencies in the information used for triangulation.

\section{RESULTS}

Spruce bark beetles, wildfire, and people on the Kenai Peninsula, Alaska

Spruce bark beetle (SBB; Dendroctonus rufipennis) outbreak, a pulse-ecosystem driver, is a prevalent natural disturbance in forests of the western Kenai Peninsula in south-central Alaska
(Fig. 2; Berg and Anderson 2006, Sherriff et al. 2011). Outbreaks have occurred approximately once every 50 years for at least the last 250 years (Berg and Anderson 2006, Berg et al. 2006). A series of warm summers led to a SBB outbreak of unprecedented size in the 1990s (Table 1; Berg et al. 2006). More than a million hectares of mature white spruce (Picea glauca) and Lutz spruce (Picea lutzii) were affected and 30 million trees were killed per year (Berg et al. 2006, Werner et al. 2006).

Fig. 2. Maps of the Kenai Peninsula Alaska, including the Kenai National Wildlife Refuge. Map A depicts spruce bark beetle (Dendroctonus rufipennis) outbreak perimeters from 1989-2000. Map B depicts wildfire perimeters from 1940-2010.

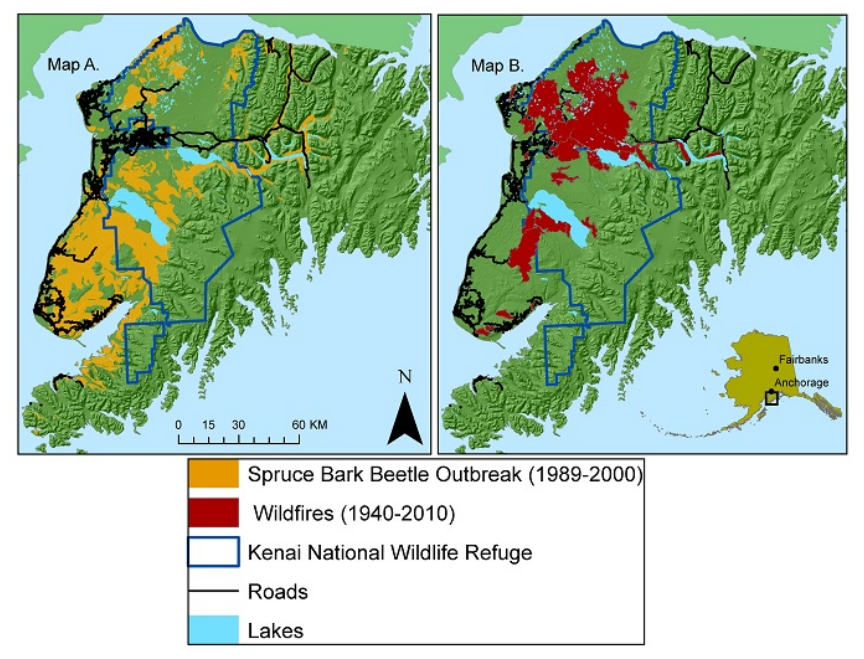

The SBB-outbreak pulse markedly changed both ecosystem structure and function (Table 1). Old-growth spruce trees dropped their needles, forest canopies opened, understories dried, and snags fell (Schulz 1995, 2003). In some postoutbreak stands Calamagrostis canadensis, a native boreal early-succession grass, dominated (Lieffers et al. 1993, Holsten et al. 1995, Boucher and Mead 2006). It formed a thick mat of dead organic matter, or litter, that continues to hinder the establishment of white-spruce seedlings and has extended the grass's period of ecological dominance (Lieffers et al. 1993). Calamagrostis often grows to 1.5 $\mathrm{m}$ tall and is highly flammable, particularly before green-up and during senescence (Holsten et al. 1995, Schulz 1995).

Wildfires, another pulse-ecosystem driver, also occur in southcentral Alaska and play a critical role in shaping ecosystem structure and function (Table 1 and Fig. 2; Berg and Anderson 2006, Morton et al. 2006). As a result of the SBB outbreak, Kenai Peninsula residents have been concerned that ecological change (i.e., Calamagrostis spread and increased/drier fuel loads), interacting with the press of warming climate, could cause larger, more frequent, and severe wildfires that threaten public safety, which is an ecosystem disservice (Flint 2006). In response, a committee of federal, state, local, and Native-lands natural resource managers was established to address this fire risk. Members developed the All Lands/All Hands Action Plan, and subsequent efforts focused on (1) improving wildfire suppression and firefighter safety through better agency coordination and improved firefighter resources, (2) developing homeowner fire- 
Table 1. Press- and pulse-ecosystem drivers, feedbacks, ecological change, ecosystem services, disservices, and associated management actions on the Kenai Peninsula, Alaska. SBB = spruce bark beetle (Dendroctonus rufipennis).

\begin{tabular}{|c|c|c|c|c|c|c|c|}
\hline Ecosystem Driver & Press & Pulse & $\begin{array}{l}\text { Feedbacks to other } \\
\text { ecosystem drivers }\end{array}$ & Ecological change & Ecosystem Service & $\begin{array}{l}\text { Ecosystem } \\
\text { Disservice }\end{array}$ & Management Action \\
\hline SBB Outbreak & & Yes & $\begin{array}{l}\text { Increases wildfire } \\
\text { risk. }\end{array}$ & $\begin{array}{c}\text { Forest cover } \\
\text { Reduced. } \\
\text { Fuel loads } \\
\text { dry. } \\
\text { Calmagrostis spreads } \\
\text { and dominates. }\end{array}$ & $\begin{array}{c}\text { Improves views of } \\
\text { Cook Inlet. }\end{array}$ & $\begin{array}{l}\text { Increases wildfire } \\
\text { risk. }\end{array}$ & $\begin{array}{l}\text { Community education } \\
\text { and outreach. } \\
\text { Salvage logging. }\end{array}$ \\
\hline Wildfire & & Yes & $\begin{array}{l}\text { Increases } \mathrm{CO}_{2} \\
\text { emissions. }\end{array}$ & $\begin{array}{l}\text { Initiates ecosystem } \\
\text { succession. }\end{array}$ & $\begin{array}{l}\text { Improves views of } \\
\text { Cook Inlet. } \\
\text { Reduces perceived } \\
\text { risk of future fire. }\end{array}$ & $\begin{array}{l}\text { Property damage. } \\
\text { Personal harm. }\end{array}$ & $\begin{array}{l}\text { Wildfire suppression. } \\
\text { Mechanical thinning. } \\
\text { Community outreach } \\
\text { and education } \\
\text { (Firewise). } \\
\text { Some prescribed } \\
\text { burning. }\end{array}$ \\
\hline Climate Change & Yes & & $\begin{array}{c}\text { Increases SBB } \\
\text { outbreak. } \\
\text { Increases wildfire } \\
\text { risk. }\end{array}$ & Dries fuel loads. & & & \\
\hline $\begin{array}{l}\text { Semirural } \\
\text { residential } \\
\text { expansion }\end{array}$ & Yes & & $\begin{array}{l}\text { Natural wildfires } \\
\text { suppressed } \\
\text { in Kenai National } \\
\text { Wildlife Refuge. }\end{array}$ & $\begin{array}{l}\text { Fuel loads buildup. } \\
\text { Early succession } \\
\text { forests lost in } \\
\text { wilderness. }\end{array}$ & $\begin{array}{l}\text { Risk of escaped } \\
\text { wildfire reduced. }\end{array}$ & $\begin{array}{l}\text { Wildlife habitat } \\
\text { lost. } \\
\text { Increases SBB } \\
\text { outbreak risk. }\end{array}$ & $\begin{array}{c}\text { Community outreach } \\
\text { and education. } \\
\text { Mechanical thinning. } \\
\text { Some prescribed } \\
\text { burning. }\end{array}$ \\
\hline
\end{tabular}

wise education and outreach programs, (3) incentivizing defensible space on private land, (4) reducing fuels on public land, (5) restoring ecosystems, (6) and supporting initiatives for firesensitive land-use planning. Many elements of the All Lands/All Hands plan were effective. In 2005, approximately 1500 hectares of hazardous fuels were strategically removed. Although 2005 was a record fire year, no homes burned, which was attributed to fuel-reduction treatments.

Despite successes, key challenges still hinder aspects of postoutbreak wildfire management. Consequences of pressing climate change for ecosystem processes and post SBB-outbreak fire regime are poorly understood, making it difficult to develop management strategies that are robust to future conditions. Additionally, managers of the Kenai National Wildlife Refuge, a member of the All Lands/All Hands group, face tough decisions regarding the suppression of natural, i.e., lightning-caused, wildfires in designated wilderness, despite their ecologically critical role (Morton et al. 2006). The press-ecosystem driver of population expansion on the Kenai Peninsula, few egress routes, and public pressure to suppress wildfire limit the refuge's ability to allow natural wildfires to burn (Table 1; Morton et al. 2006). Residentialdevelopment is pronounced in semirural land abutting the refuge (Fig. 2), and home densities are equivalent to those in areas of the Intermountain West in the continental United States (Kenai Peninsula Borough 2012). Many homes are located along roads built for post SBB-outbreak salvage logging, in places where fire risk is higher (Berg 2000, Hansen 2013).

Understandably, residents are concerned about personal safety and property damage due to wildfire, a clear ecosystem disservice. However, this residential area is also attractive to some homeowners because of the ecosystem services that are directly provisioned as a consequence of the SBB outbreak and subsequent wildfires. For example, the occurrence of a wildfire or SBB outbreak close to homes was associated with increased property values, likely resulting from improved views of Cook Inlet (Fig. 3; Hansen and Naughton 2013). Thus, the ultimate effects of these ecosystem drivers on human well-being are nuanced and unclear. Applying the adapted press-pulse framework to management of natural disturbances on the Kenai Peninsula helped demonstrate how coordination between

Fig. 3. Semirural home in south-central Alaska abutting the Kenai National Wildlife Refuge. In this area, sprucce bark beetle (Dendroctonus rufipennis) outbreak and wildfires have opened up views of Cook Inlet, potentially explaining the associated increases in property values. Photo credit: W. D. Hansen, edited by: A. Olsson

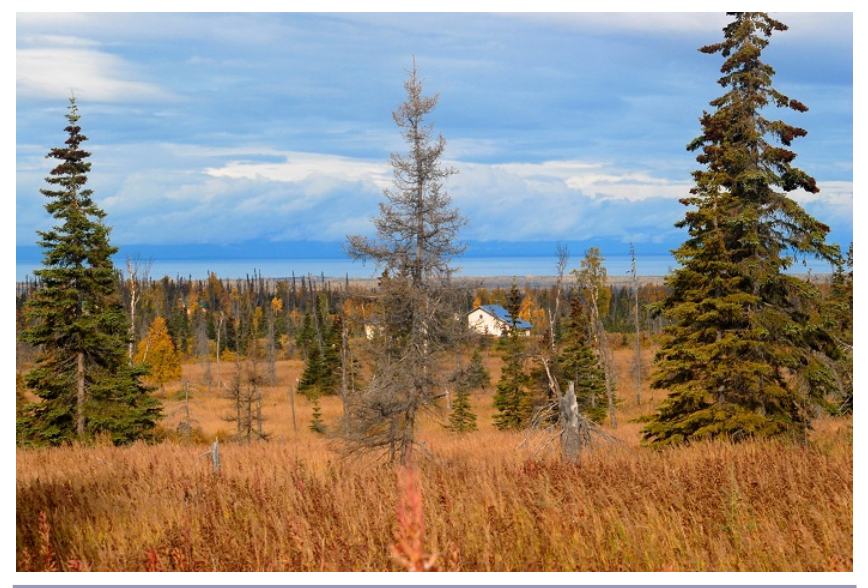


Table 2. Press- and pulse-ecosystem drivers, feedbacks, ecological change, ecosystem services, disservices, and associated management actions in the Yukon River drainage, Alaska. King salmon (Oncorhynchus tshawytscha).

\begin{tabular}{|c|c|c|c|c|c|c|c|}
\hline $\begin{array}{l}\text { Ecosystem } \\
\text { Driver }\end{array}$ & Press & Pulse & $\begin{array}{l}\text { Feedbacks to other } \\
\text { ecosystem drivers }\end{array}$ & Ecological Change & Ecosystem Service & $\begin{array}{l}\text { Ecosystem } \\
\text { Disservice }\end{array}$ & Management Action \\
\hline $\begin{array}{l}\text { King salmon } \\
\text { migration }\end{array}$ & & Yes & & $\begin{array}{c}\text { Provides nutrient } \\
\text { subsidy to terrestrial } \\
\text { and freshwater systems. }\end{array}$ & $\begin{array}{l}\text { Accessible protein } \\
\text { source. } \\
\text { Defines cultural } \\
\text { livelihoods. }\end{array}$ & & \\
\hline Climate change & Yes & & $\begin{array}{l}\text { Reduces king } \\
\text { salmon survival. }\end{array}$ & $\begin{array}{l}\text { Reduces river depth. } \\
\text { Increases river-water } \\
\text { temperature. } \\
\text { Alters river-prey } \\
\text { distributions and flow } \\
\text { regimes. } \\
\text { Uncertain ocean } \\
\text { impacts. }\end{array}$ & & $\begin{array}{l}\text { Reduces available } \\
\text { king salmon for } \\
\text { harvest. }\end{array}$ & $\begin{array}{c}\text { Eliminate commercial } \\
\text { harvest. } \\
\text { Reduce subsistence } \\
\text { harvest. } \\
\text { Research causes of } \\
\text { salmon decline. }\end{array}$ \\
\hline Ocean bycatch & & Yes & $\begin{array}{c}\text { Reduces king } \\
\text { salmon survival. }\end{array}$ & $\begin{array}{l}\text { Reduces salmon } \\
\text { nutrient subsidy. }\end{array}$ & & $\begin{array}{l}\text { Reduces available } \\
\text { king salmon for } \\
\text { harvest. }\end{array}$ & $\begin{array}{c}\text { Eliminate commercial } \\
\text { harvest. } \\
\text { Reduce subsistence } \\
\text { harvest. } \\
\text { Research causes of } \\
\text { salmon decline. }\end{array}$ \\
\hline
\end{tabular}

different natural resource agencies can lead to more effectively managing the consequences of interacting press- and pulseecosystem drivers. It also highlights how paradoxical outcomes that arise from counterintuitive trade-offs between ecosystem services and disservices can constrain institutions, making it difficult to develop effective and widely embraced strategies.

\section{Yukon River king salmon management}

The Yukon River drainage (YRD) is the fourth largest in North America and extends more than $3200 \mathrm{~km}$ from western Alaska to the river's origin in the Yukon Territory, Canada (Fig. 4). The YRD encompasses approximately $850,000 \mathrm{~km}^{2}$. More than 50 communities dot the riverbanks. Most communities are rural and predominately indigenous. They are often only accessible by plane, snowmobile, or barge. Commercial goods are expensive, even by Alaskan standards (Loring and Gerlach 2009); and mean per capita income for Alaska Natives is approximately $\$ 16,000$ in 2012 inflation-adjusted U.S. dollars (U.S. Census Bureau 2014). YRD residents rely on the harvest of wild foods, i.e., ecosystem services, from the river and watershed, as they have for thousands of years. Fifty-seven percent of required calories come from wild foods in the Yukon-Koyukuk region (Wolfe 2000).

In summer, king salmon and chum salmon (Oncorhynchus keta), a pulse-ecosystem driver, migrate from the ocean up the Yukon River and tributaries to spawning grounds. They lay eggs, which are fertilized in the gravel, and die (Table 2). The carcasses of the adult salmon decompose, providing a nutrient subsidy to the terrestrial and fresh-water ecosystems. The next generation of salmon emerges and slowly returns to the ocean, overwintering in the river (ADF\&G Chinook Salmon research Team 2013). Salmon make up a substantial portion of the wild foods that are harvested in the YRD (Hansen et al. 2013b). This food source is a critical ecosystem service and plays a central role in food security (Table 2). It has been estimated that salmon make up as much as $59 \%$ of the total annual harvest of fish and game in the YRD (Brown and Jallen 2012). Families often stay at summer fish camps where salmon are caught and processed.
Fig. 4. Map of the Yukon River Drainage and communities.

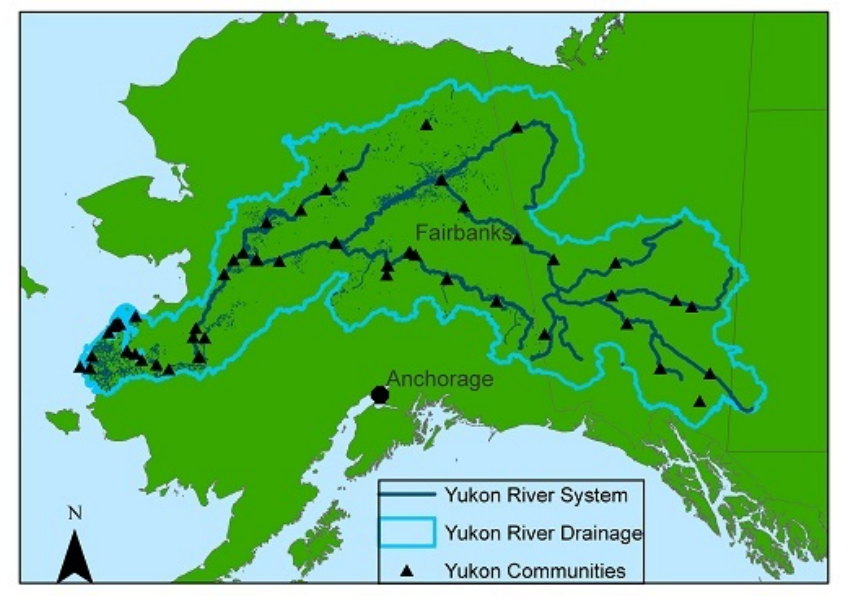

The fish are either consumed or sold commercially. Salmon have been sustainably harvested in the YRD for generations. However, in 1998, the king salmon population crashed, and runs have remained substantially smaller. The reasons for the crash are unclear. Salmon spend part of their life in the river system, where water temperatures are warming, flow regimes are changing, and prey distributions are shifting because of climate change, a pressecosystem driver (Table 2; ADF\&G Chinook Salmon Research Team 2013). They spend the rest of their lives in the ocean, where our understanding of the factors that affect salmon survival and how those factors are changing is incomplete. Further, pulses of commercial bycatch in the ocean are pronounced (Table 2; Stram and Evans 2009). A mean of 23,290 and 38,245 king salmon per year have been accidentally caught in the Gulf of Alaska and Bering Sea/Aleutian Island commercial groundfish fisheries, respectively, over the last 15 years (NOAA Fisheries 2014). 
Following the crash, state and federal agencies were tasked with conserving king salmon while still meeting people's food needs. Managers have struggled to find a sustainable balance and meet their objectives with this mandate (Loring and Gerlach 2010). A treaty with Canada was signed in 2001 establishing a commitment to annually meet king salmon escapement goals, i.e., the number of salmon that must migrate across the Alaska/Canada border to ensure population persistence. Salmon are managed to first meet these escapement requirements and only then to provide for harvest. As runs remained small, managers implemented conservation measures such as subsistence fishing closures and eliminating the commercial fishery (ADF\&G Chinook Salmon Research Team 2013). Recently, managers asked fishers to voluntarily reduce their king salmon harvest to $25 \%$ of normal catch. However, in 2007, 2008, 2010, 2012, and 2013 escapement goals were not met. Conservation measures to meet escapement have sometimes constrained local harvest, threatening food security (Loring and Gerlach 2010).

One key barrier to successfully balancing community need with conservation has been that king salmon are challenging to study (ADF\&G Chinook Salmon Research Team 2013). It is hard to manage any system when you do not know where, when, or why a problem is occurring. Both the river and ocean systems are complex, with many interacting drivers, making it difficult to develop sustainable solutions that address root causes. Conservation measures are implemented based on within-year monitoring and the best modeling of salmon-population dynamics possible. However, because of the incomplete understanding of factors affecting king salmon populations, model uncertainty can be large. In 2009, midseason run projections led to concern that escapement goals would not be met, and widespread fishing closures were implemented. In the end, escapement goals were exceeded by 12,000 fish that could have been harvested by residents (Loring and Gerlach 2010).

Despite challenges, novel adaptations have arisen. In 2001, the Kwik'Pak Fisheries Corporation was established, representing six lower-YRD communities. Initially, they commercially marketed king salmon. Because of the crash, Kwik'Pak transitioned to marketing Yukon chum. In other rivers, chum are poorer quality than king salmon. Because of the long journey Yukon chum endure, their oil content, which provides energy for the long journey and is a measure of quality, rivals that of king salmon from other river drainages. Working with Kwik'Pak, managers and fishers collaboratively developed techniques that allow safe harvest of chum while avoiding king salmon. Fishers often use fish wheels (Fig. 5) and monitor to ensure that any caught king salmon are immediately released alive. In 2012, Kwik'Pak Fisheries employed 542 people in their organization and took deliveries from 442 fishers. Characterizing YRD king salmon conservation with the press-pulse framework helped to illustrate challenges of managing complex systems with multiple, poorly understood ecosystem drivers, particularly when mandated objectives require balancing the provision of important ecosystem services with more ecologically centered goals such as species conservation. However, it also shows that proactive thinking and cooperation, when flexibility is permitted, can yield innovative adaptations, despite system complexity and conflicting interests.
Fig. 5. Fish wheel used by Yukon River fishers to catch king (Oncorhynchus tshawytscha) and chum (O. keta) salmon. Photo credit: K. Kielland, edited by: A. Olsson

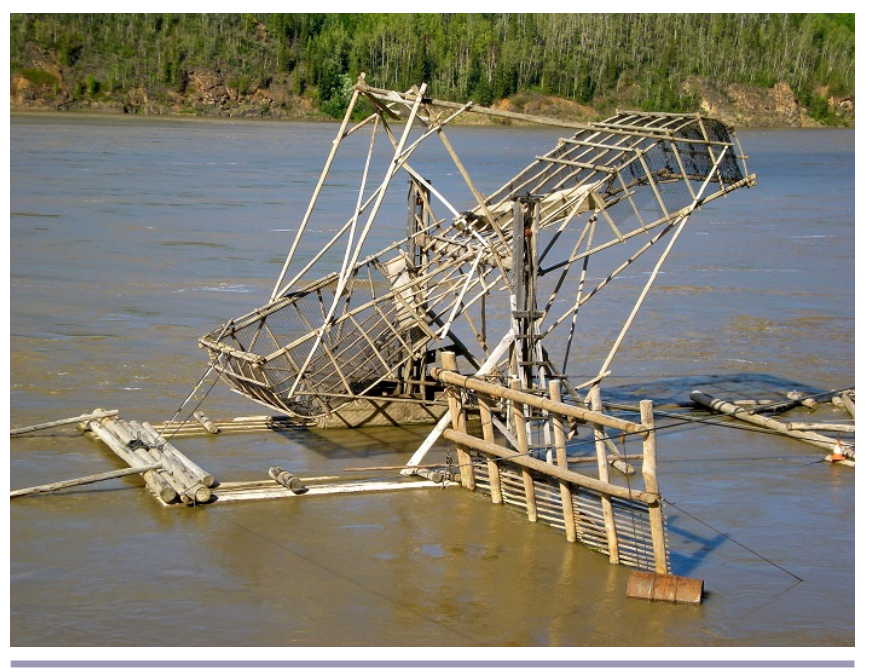

\section{DISCUSSION}

I adapted and applied the press-pulse SES framework (Collins et al. 2011) to conduct case studies characterizing natural resource management issues in Alaska. The framework helped identify some key press- and pulse-ecosystem drivers in each system, determine interactions between drivers, link drivers to their associated ecological changes and subsequent social consequences, and elucidate management actions. Using this framework was valuable for revealing both current barriers to implementing ES management and innovative adaptations that could serve as models for solutions in other contexts.

\section{Barriers to ecosystem stewardship management}

Institutional constraints dictating the goals or terms of management were a barrier to implementing ES management in the Alaskan case studies. For example, on the Kenai Peninsula, the provision of ecosystem services such as pleasing views has fostered residential growth in high fire-risk areas. This growth constrains managers from allowing natural wildfires to play their ecologically critical role. Institutional constraints, either dictated by the public or from within the organization, are a common barrier to innovative management (Olsson et al. 2004, Beier et al. 2009). Nevertheless, transformation that ameliorates institutional constraints and fosters flexibility can occur (Olsson et al. 2004, Westley et al. 2011). For example, overharvesting, increasing sediment runoff, and changing climate were degrading the Australian Great Barrier Reef. In 1998, this stimulated reorganization of the institutions tasked with the reef's management (Olsson et al. 2008). However, many factors in addition to environmental crises often must come together synchronously to trigger transformative institutional change (Olsson et al. 2004). In the Great Barrier Reef example, alarming reef degradation coincided with large turnovers of agency personnel, which facilitated internal reorganization; a successful information campaign that changed perceptions of the reef's condition; and the opening of a narrow political window of 
opportunity to get parliament approval for agency reorganization (Olsson et al. 2008). Although environmental crises could become increasingly common, opportunities to remove institutional constraints through transformation are likely to remain rare because of mismatching spatial, temporal, and organizational scales between social and ecological systems (Cumming et al. 2006). Instead, successfully implementing ES management may require more incremental approaches that explicitly acknowledge and account for the institutional boundaries within which managers must operate.

An additional barrier to implementing ES management in the Alaska case studies was an incomplete understanding of the pressand pulse-ecosystem drivers at play. In particular, current management of declining king salmon runs is greatly constrained by not knowing what is causing reductions in populations. By definition, SESs are complex and unpredictable. Emergent properties are prevalent and surprises are likely to persist (Holling 2001, Doak et al. 2008). However, the foundation of resource management is accurately anticipating the consequences of decisions (Führer 2000, Clark et al. 2001). Thus, agencies often manage systems for specific outcomes by monitoring and manipulating a single or small set of well-understood variables. Confounding variables such as incremental climate change may garner less attention or not be incorporated into decision-making frameworks, but can unpredictably alter expected consequences of management actions (Polasky et al. 2011). Social-ecological outcomes are often determined by surprising interactions between many variables. Implementing ES management will require shifting away from a command-and-control mentality to one that embraces the inevitability of persisting uncertainty and finds ways to foster innovation through flexibility.

\section{Generalizable principles}

As we enter the Anthropocene, strategies to foster resilience and redirect SESs toward trajectories of sustainable humanenvironment interaction are of critical importance. Natural resource managers could play a central role in shaping sustainable trajectories. However, as identified in the Alaskan case studies and throughout the literature, key barriers hinder the implementation of ES management. I posit some generalizable principles, or strategic elements, based on the Alaskan case studies and examples from the broader literature that may help managers overcome these barriers (Table 3; Walters and Holling 1990, Walker et al. 2002, Ostrom 2007, Carpenter et al. 2009, Turner et al. 2012). Principles for ES exist, largely focusing on transformative change or providing guidance at planetary scales (Chapin et al. 2010, 2011). In complementary fashion, principles presented here are meant to facilitate the use of ES management by managers at more local scales when transformative institutional change is unlikely.

Spend equal time thinking about both the ecosystem and the people who will affect and be affected by management decisions Human well-being and ecosystems are inextricably linked (Liu et al. 2007). As ES management is implemented, affected people will be the ones who hold managers accountable. It is critical to balance a rigorous understanding of the ecological impacts of a management action with identification of key stakeholder groups and determining how those groups are likely to perceive that action. Effective ES management is possible if we look for win- win solutions that are perceived as good for people and good for the ecosystem, or compromises that minimize negative trade-offs between the two.

Table 3. Generalizable principles to foster ecosystem stewardshipbased natural resource management, particularly at local scales when transformative institutional change is unlikely.

\begin{tabular}{lc}
\hline \hline \multicolumn{1}{c}{ Generalizable Principle } & Characteristic \\
\hline $\begin{array}{l}\text { Account for people and ecosystems in } \\
\text { management actions }\end{array}$ & $\begin{array}{c}\text { Human-nature } \\
\text { interactions }\end{array}$
\end{tabular}

Consider historical and current system dynamics, but manage flexibly for the future

Identify interactions between organizational, temporal, and spatial scales

Embrace multiple causes in addition to multiple objectives

Acknowledge there are no panaceas; success will be incremental

Resilience

Cross-scale interactions

Multiple causation

Incremental success

The win-win solutions are often hard to determine. How stakeholders weigh the perceived consequences of management actions is based on sometimes-paradoxical trade-offs between benefits of affected ecosystem services and costs of disservices (Fig. 1). The consequences of natural disturbances are often thought to negatively affect people living nearby. However, disturbances ranging from insect outbreaks to wildfire can also have counterintuitive, positive effects on human well-being (Holmes et al. 2006, Donovan et al. 2007, Hansen and Naughton 2013). For example, on the Kenai Peninsula, the occurrence of nearby wildfires was associated with increases in semirural property values, likely because of the emergence of aesthetically pleasing views (Hansen and Naughton 2013). Fire managers on the Kenai Peninsula may bolster support for prescribed fire, used to create firebreaks that would allow natural wildfire to burn safely (Kenai National Wildlife Refuge Fire Management Staff 2001), if they design treatments to enhance residential views.

Consider historical and current dynamics, but manage flexibly for the future

Managing for resilience and avoiding regime shifts will require characterizing past dynamics to help maintain and enhance characteristics of current SESs. ES management should bolster current diversity, foster adaptive capacity, and encourage the protection of and investment in natural, social, and human capital (Chapin et al. 2009b). However, implementing ES management also requires proactive governance that accounts for and embraces future changes (Magness et al. 2012, Turner et al. 2012). We must identify social and ecological indicators of system dynamics and begin to rigorously collect data on indicators (Turner et al. 2012). These data will improve our current understanding and narrow the range of plausible futures, helping to characterize the nature of changing systems and encouraging more proactive, flexible governance. In the YRD, collection of some valuable indicators, including the availability and past 
harvest levels of other fish and game species, and the amount of groceries purchased, could inform more flexible strategies. This would help managers better assess the potential for resource substitutions to ameliorate food insecurity resulting from kingsalmon conservations measures (Hansen et al. 2013b). On the Kenai Peninsula, data on postwildfire and post-SBB outbreak forest regeneration would provide insights into likely forestsuccession trajectories and associated feedbacks to future disturbance regimes (Turner et al. 2012).

Identifying and collecting data on key indicators will require that we use the best science when it is available, but not be paralyzed by inaction when scientific knowledge is incomplete. Although science should play a central role in characterizing systems and can help facilitate proactive governance, gaps in our conceptual understanding of SESs persist. Critical advancements have also been made based on the practical experience of natural resource managers in scientifically uncertain conditions. For example, the All Lands/All Hands group has invested resources to understand postwildfire Calamagrostis dynamics and have experimented with forest restoration techniques. Integrating science with practitioner experience will provide the most comprehensive foundation for ES management (U.S. Forest Service 2010).

Identify interactions between organizational, temporal, and spatial scales

In SESs, system properties often result from interactions between drivers operating at different hierarchical organizational, spatial, and temporal scales (Redman et al. 2004). In the YRD, meeting escapement requirements to Canada is predicated on drivers that affect salmon survival and recruitment in both the Canadian and Alaskan portions of the YRD, as well as drivers acting thousands of kilometers away in the Bering Strait (ADF\&G Chinook Salmon Research Team 2013). Managers on the Yukon River may have little conservation success if they do not account for pressures in the marine component of salmon life history. Implementing ES management will require consideration of these interactions, particularly when their cross-scalar nature, e.g., over multiple management jurisdictions including international boundaries, masks their cascading social-ecological implications (Lovecraft 2007, U.S. Fish and Wildlife Service 2010). Regular collaboration between agencies to share diverse expertise about resource-management challenges, such as managing king salmon with their complex life histories, will help better incorporate and account for interacting system drivers across scales. On the Kenai Peninsula, The All Lands/All Hands group provides an excellent example of multijurisdictional collaboration. By sharing unique areas of expertise, coordinating and effectively allocating limited agency resources, and converging on common objectives for resource management, the group has been able to develop a more holistic understanding of the system and has gained substantial insight.

\section{Embrace multiple causes in addition to multiple objectives}

Although natural resource management has increasingly recognized the need to manage for multiple objectives (Chapin et al. 2010), there also is a need to identify multiple causes. Our understanding of SES is usually incomplete. However, it is increasingly apparent that system dynamics are rarely caused by a single or even small set of drivers (Holling 2001, Marcot et al. 2012, Cilliers et al. 2013). In both case studies, management strategies largely focused on pulses: SBB outbreak and wildfire on the Kenai Peninsula, and king salmon run size in the YRD. However, there were also pressing drivers that shaped the consequences of those pulses. For example, regardless of the effects of subsistence fishing closures that were meant to help restore king salmon runs, changing climate may be reducing spawning success and fitness (ADF\&G Chinook Salmon Research Team 2013), decreasing conservation effectiveness. The influences of many pressing drivers are inevitable; i.e., a manager cannot stop climate change. However, by accepting and better accounting for the multiple causes of social-ecological challenges, as much as is allowed within existing institutions, we can begin to understand how pressing variables confound management outcomes. This paradigm shift could help foster increasingly proactive governance that more accurately visualizes plausible futures and fosters adaptation. By realizing the profound longterm influence of multiple drivers on the king salmon population, the Kwik'Pak Fisheries Corporation envisioned a new future of commercially marketing chum salmon and adapted successfully.

There are no panaceas; success will be incremental

There are no panacea frameworks or strategies to prescriptively implement ES management (Ostrom 2007, Ostrom et al. 2007, Ostrom and Cox 2010). Widespread radical institutional reorganization is unlikely in many situations, as are vast improvements in our social-ecological understanding. Thus, successful implementation of ES management is likely to occur through incremental steps. As ES management is implemented, we need to temper expectations. However, incremental steps accumulate over time, such as the Kwik'Pak Fisheries Corporation in the YRD. The innovation of marketing chum salmon instead of king salmon currently benefits relatively few people economically, and is likely to have only modest effects on king salmon population health in the YRD. However, the corporation serves as a potential example and inspiration for larger-scale solutions. It is possible to replicate the business model in other communities? Could YRD communities substitute other species in place of king salmon, alleviating pressure on their struggling populations (Hansen et al. 2013b)? Given current barriers, implementing ES management will likely require continued and persistent commitment to experimenting with new strategies, writing grants to support experimentation, and the willingness to be wrong while minimizing consequences of being wrong.

\section{From theory to application}

The generalizable principles presented in this paper have the potential to help managers overcome barriers and introduce ES management. Choosing broadly applicable case studies for this research and strongly supporting the principles with other examples from the literature suggest that, as strategic elements, the principles are likely to be of great utility in a number of systems. However, they are still posited from the results of systemspecific cases. Thus, the applicability of these principles to other settings must be rigorously evaluated. Collaborations between natural resource practitioners and researchers are needed to develop mechanisms for assessing the utility of these principles in diverse settings, applying them when appropriate, and tracking progress when they are implemented. This will help us to ultimately determine their effectiveness under different conditions in actually altering trajectories of human-environment interactions and avoiding unwanted social-ecological regime shifts. 


\section{CONCLUSION}

As the human population grows and pressures on ecosystem services build, society is faced with the increasingly unrelenting challenge of redirecting SESs toward sustainable trajectories of human-environment interaction. Natural resource managers are poised to implement ES management strategies and play a central role in fostering sustainable outcomes. Barriers persist to management based on ES principles. However, there are also great opportunities to overcome barriers, drawing on key principles. These principles include (1) accounting for people and ecosystems in management actions; (2) considering historical and current system dynamics, but managing flexibly for the future; (3) identifying interactions between organizational, temporal, and spatial scales; (4) embracing multiple causes in addition to multiple objectives; and (5) acknowledging that there are no panaceas and that success will be incremental. Once further refined and evaluated, such principles could provide a strong foundation for ushering in a new era of natural resource management, avoiding unwanted regime shifts and fostering more sustainable relationships between people and the environment.

Responses to this article can be read online at: http://www.ecologyandsociety.org/issues/responses. php/6907

\section{Acknowledgments:}

Ithank J. Morton, E. Berg, andmembers of the All Lands/All Hands group for insights into the social and ecological complexities of the Kenai Peninsula. I thank T. Chapin, G. Kofinas, and M. Turner for helping improve earlier versions of this manuscript. I thank $A$. Olsson for photo editing and $K$. Kielland for providing a photo. This paper is based on work supported by a National Science Foundation Graduate Research Fellowship (DGE-1242789) and the National Science Foundation (0654441; IGERT: Global-Local Interactions: Resilience and Adaption of Social-Ecological Systems in a Rapidly Changing North). Further funding was provided by the Alaska Climate Science Center, Scenarios Network for Alaska and Arctic Planning, and Alaska EPSCoR (EPS-0701898) from the National Science Foundation. The views expressed in the paper are those of the author and do not represent those of the National Science Foundation.

\section{LITERATURE CITED}

ADF\&G Chinook Salmon Research Team. 2013. Chinook salmon stock assessment and research plan. Special Publication No. 13-01. Alaska Department of Fish and Game, Anchorage, Alaska, USA. [online] URL: http://www.adfg.alaska.gov/static/home/news/ hottopics/pdfs/chinook_research_plan.pdf

Armitage, D., F. Berkes, A. Dale, E. Kocho-Schellenberg, and E. Patton. 2011. Co-management and the co-production of knowledge: learning to adapt in Canada's Arctic. Global Environmental Change 21:995-1004. http://dx.doi.org/10.1016/j. gloenvcha.2011.04.006

Barnosky, A. D., E. A. Hadly, J. Bascompte, E. L. Berlow, J. H. Brown, M. Fortelius, W. M. Getz, J. Harte, A. Hastings, P. A.
Marquet, et al. 2012. Approaching a state shift in Earth's biosphere. Nature 486:52-58. http://dx.doi.org/10.1038/nature11018

Baumgärtner, S., C. Becker, K. Frank, B. Müller, and M. Quaas. 2008. Relating the philosophy and practice of ecological economics: the role of concepts, models, and case studies in interand transdisciplinary sustainability research. Ecological Economics 67:384-393. http://dx.doi.org/10.1016/j.ecolecon.2008.07.018

Beier, C. M., A. L. Lovecraft, and F. S. Chapin III. 2009. Growth and collapse of a resource system: an adaptive cycle of change in public lands governance and forest management in Alaska. Ecology and Society 14(2): 5. [online] URL: http://www. ecologyandsociety.org/vol14/iss2/art5/

Berg, E. E. 2000. Studies in the wilderness areas of the Kenai National Wildlife Refuge: fire, bark beetles, human development, and climate change. Pages 63-67 in S. F. McCool, D. N. Cole, W. T. Borrie, and F. O'Loughlin, editors. Proceedings of wilderness science in a time of change conference. Volume 3. Wilderness as a place for scientific inquiry; 1999 Missoula, MT. Rocky Mountain Research Station, U.S. Forest Service, Ogden, Utah, USA.

Berg, E. E., and R. S. Anderson. 2006. Fire history of white and Lutz spruce forests on the Kenai Peninsula, Alaska, over the last two millennia as determined from soil charcoal. Forest Ecology and Management 227:275-283. http://dx.doi.org/10.1016/j. foreco.2006.02.042

Berg, E. E., J. D. Henry, C. L. Fastie, A. D. De Volder, and S. M. Matsuoka. 2006. Spruce beetle outbreaks on the Kenai Peninsula, Alaska, and Kluane National Park and Reserve, Yukon territory: relationship to summer temperatures and regional differences in disturbance regimes. Forest Ecology and Management 227:219-232. http://dx.doi.org/10.1016/j.foreco.2006.02.038

Biggs, R., S. R. Carpenter, and W. A. Brock. 2009. Turning back from the brink: detecting an impending regime shift in time to avert it. Proceedings of the National Academy of Sciences of the United States of America 106:826-831. http://dx.doi.org/10.1073/ pnas.0811729106

Boucher, T. V, and B. R. Mead. 2006. Vegetation change and forest regeneration on the Kenai Peninsula, Alaska following a spruce beetle outbreak, 1987-2000. Forest Ecology and Management 227:233-246. http://dx.doi.org/10.1016/j.foreco.2006.02.051

Brinkman, T. J., G. P. Kofinas, W. D. Hansen, F. S. Chapin III, and T. S. Rupp. 2013. A new framework to manage hunting. Why we should shift focus from abundance to availability. Wildlife Professional 7(3):38-43.

Brown, C., and D. Jallen. 2012. Options for amounts reasonably necessary for subsistence uses of salmon: Yukon management area. Special Publication No. BOF 2012-08. Division of Subsistence, Alaska Department of Fish and Game, Fairbanks, Alaska, USA.

Carpenter, S. R., H. A. Mooney, J. Agard, D. Capistrano, R. S. Defries, S. Díaz, T. Dietz, A. K. Duraiappah, A. Oteng-Yeboah, H. M. Pereira, et al. 2009. Science for managing ecosystem services: beyond the Millennium Ecosystem Assessment. Proceedings of the National Academy of Sciences of the United States of America 106:1305-1312. http://dx.doi.org/10.1073/ pnas. 0808772106 
Chapin, F. S., III. 2009. Managing ecosystems sustainably: the key role of resilience. Pages 29-53 in F. S. Chapin III, G. P. Kofinas, and C. Folke, editors. Principles of ecosystem stewardship: resilience-based natural resource management in a changing world. Springer, New York, New York, USA. http://dx.doi. org/10.1007/978-0-387-73033-2_2

Chapin, F. S., III, S. R. Carpenter, G. P. Kofinas, C. Folke, N. Abel, W. C. Clark, P. Olsson, D. M. S. Smith, B. Walker, O. R. Young, et al. 2010. Ecosystem stewardship: sustainability strategies for a rapidly changing planet. Trends in Ecology \& Evolution 25:241-249. http://dx.doi.org/10.1016/j.tree.2009.10.008

Chapin, F. S., III, C. Folke, and G. P. Kofinas. 2009b. A framework for understanding change. Pages 3-28 in F. S. Chapin III, G. P. Kofinas, and C. Folke, editors. Principles of ecosystem stewardship: resilience-based natural resource management in a changing world. Springer, New York, New York, USA. http://dx. doi.org/10.1007/978-0-387-73033-2_1

Chapin, F. S., III, G. P. Kofinas, and C. Folke, editors. $2009 a$. Principles of ecosystem stewardship: resilience-based natural resource management in a changing world. Springer, New York, New York, USA.

Chapin, F. S., III, A. L. Lovecraft, E. S. Zavaleta, J. Nelson, M. D. Robards, G. P. Kofinas, S. F. Trainor, G. D. Peterson, H. P. Huntington, and R. L. Naylor. 2006. Policy strategies to address sustainability of Alaskan boreal forests in response to a directionally changing climate. Proceedings of the National Academy of Sciences of the United States of America 103:16637-16643. http://dx.doi.org/10.1073/pnas.0606955103

Chapin, F. S., III, A. F. Mark, R. A. Mitchell, and K. J. M. Dickinson. 2012. Design principles for social-ecological transformation toward sustainability: lessons from New Zealand sense of place. Ecosphere 3(5): 40. http://dx.doi.org/10.1890/ ES12-00009.1

Chapin, F. S., III, M. E. Power, S. T. A. Pickett, A. Freitag, J. A. Reynolds, R. B. Jackson, D. M. Lodge, C. Duke, S. L. Collins, and A. G. Power. 2011. Earth stewardship: science for action to sustain the human-earth system. Ecosphere 2(8): 89. http://dx.doi. org/10.1890/ES11-00166.1

Chapin, F. S., III, S. F. Trainor, P. Cochran, H. Huntington, C. Markon, M. McCammon, A. D. McGuire, and M. Serreze. 2014. Alaska. Pages 514-536 in J. M. Melillo, Terese (T.C.) Richmond, and G. W. Yohe, editors. Climate change impacts in the united states: the third national climate assessment. U.S. Global Change Research Program. U.S. Government Printing Office, Washington, D.C., USA. [online] URL: http://nca2014. globalchange.gov/

Chapin, F. S., III, S. F. Trainor, O. Huntington, A. L. Lovecraft, E. Zavaleta, D. C. Natcher, A. D. McGuire, J. L. Nelson, L. Ray, and M. Calef. 2008. Increasing wildfire in Alaska's boreal forest: pathways to potential solutions of a wicked problem. BioScience 58:531-540. http://dx.doi.org/10.1641/B580609

Cilliers, P., H. C. Biggs, S. Blignaut, A. G. Choles, J. H. S. Hofmeyr, G. P. W. Fewitt, and D. J. Roux. 2013. Complexity, modeling, and natural resource management. Ecology and Society 18(3): 1. http://dx.doi.org/10.5751/ES-05382-180301
Clark, J. S., S. R. Carpenter, M. Barber, S. Collins, A. Dobson, J. A. Foley, D. M. Lodge, M. Pascual, R. Pielke, W. Pizer, et al. 2001. Ecological forecasts: an emerging imperative. Science 293:657-660. http://dx.doi.org/10.1126/science.293.5530.657

Collins, S. L., S. R. Carpenter, S. M. Swinton, D. E. Orenstein, D. L. Childers, T. L. Gragson, N. B. Grimm, J. M. Grove, S. L. Harlan, J. P. Kaye, et al. 2011. An integrated conceptual framework for long-term social-ecological research. Frontiers in Ecology and the Environment 9:351-357. http://dx.doi. org/10.1890/100068

Cumming, G. S., D. H. M. Cumming, and C. L. Redman. 2006. Scale mismatches in social-ecological systems: causes, consequences, and solutions. Ecology and Society 11(1): 14. [online] URL: http://www.ecologyandsociety.org/vol11/iss1/ art14

Cumming, G. S., P. Olsson, F. S. Chapin III, and C. S. Holling. 2013. Resilience, experimentation, and scale mismatches in socialecological landscapes. Landscape Ecology 28:1139-1150. http:// dx.doi.org/10.1007/s10980-012-9725-4

Daily, G. C., S. Alexander, P. R. Ehrlich, J. Lubchenco, P. A. Matson, H. A. Mooney, S. Postel, S. H. Schneider, D. Tilman, and G. M. Woodwell. 1997. Ecosystem services: benefits supplied to human societies by natural ecosystems. Issues in Ecology 2:1-16.

Doak, D. F., J. A. Estes, B. S. Halpern, U. Jacob, D. R. Lindberg, J. Lovvorn, D. H. Monson, M. T. Tinker, T. M. Williams, J. T. Wootton, et al. 2008. Understanding and predicting ecological dynamics: are major surprises inevitable? Ecology 89:952-961. http://dx.doi.org/10.1890/07-0965.1

Donovan, G. H., P. A. Champ, and D. T. Butry. 2007. Wildfire risk and housing prices: a case study from Colorado Springs. Land Economics 83:217-233.

Ehrlich, P. R., P. M. Kareiva, and G. C. Daily. 2012. Securing natural capital and expanding equity to rescale civilization. Nature 486:68-73. http://dx.doi.org/10.1038/nature11157

Flannigan, M., B. Stocks, M. Turetsky, and M. Wotton. 2009. Impacts of climate change on fire activity and fire management in the circumboreal forest. Global Change Biology 15:549-560. http://dx.doi.org/10.1111/j.1365-2486.2008.01660.x

Flint, C. G. 2006. Community perspectives on spruce beetle impacts on the Kenai Peninsula, Alaska. Forest Ecology and Management 227:207-218. http://dx.doi.org/10.1016/j.foreco.2006.02.036

Foley, J. A., R. DeFries, G. P. Asner, C. Barford, G. Bonan, S. R. Carpenter, F. S. Chapin III, M. T. Coe, G. C. Daily, H. K. Gibbs, et al. 2005. Global consequences of land use. Science 309:570-574. http://dx.doi.org/10.1126/science. 1111772

Folke, C., F. S. Chapin III, and P. Olsson. 2009. Transformations in ecosystem stewardship. Pages 103-125 in F. S. Chapin III, G. P. Kofinas, and C. Folke, editors. Principles of ecosystem stewardship: resilience-based natural resource management in a changing world. Springer, New York, New York, USA. http://dx. doi.org/10.1007/978-0-387-73033-2 5

Folke, C., T. Hahn, P. Olsson, and J. Norberg. 2005. Adaptive governance of social-ecological systems. Annual Review of 
Environment and Resources 30:441-473. http://dx.doi.org/10.1146/ annurev.energy.30.050504.144511

Führer, E. 2000. Forest functions, ecosystem stability and management. Forest Ecology and Management 132:29-38. http:// dx.doi.org/10.1016/S0378-1127(00)00377-7

Ginter, J. J. C. 1995. The Alaska community development quota fisheries management program. Ocean \& Coastal Management 28:147-163. http://dx.doi.org/10.1016/0964-5691(95)00069-0

Hansen, W. D. 2013. Linked disturbance interactions in southcentral Alaska: implications for ecosystems and people. Thesis. University of Alaska Fairbanks, Fairbanks, Alaska, USA.

Hansen, W. D., T. J. Brinkman, F. S. Chapin III, and C. Brown. 2013b. Meeting indigenous subsistence needs: the case for prey switching in rural Alaska. Human Dimensions of Wildlife 18:109-123. http://dx.doi.org/10.1080/10871209.2012.719172

Hansen, W. D., T. J. Brinkman, M. Leonawicz, F. S. Chapin III, and G. P. Kofinas. 2013a. Changing daily wind speeds on Alaska's north slope: implications for rural hunting opportunities. Arctic 66:446-458. http://dx.doi.org//10.14430/arctic4331

Hansen, W. D., and H. T. Naughton. 2013. The effects of a spruce bark beetle outbreak and wildfires on property values in the wildland-urban interface of south-central, Alaska, USA. Ecological Economics 96:141-154. http://dx.doi.org/10.1016/j. ecolecon.2013.10.009

Holling, C. S. 2001. Understanding the complexity of economic, ecological, and social systems. Ecosystems 4:390-405. http://dx. doi.org/10.1007/s10021-001-0101-5

Holmes, T. P., E. A. Murphy, and K. P. Bell. 2006. Exotic forest insects and residential property values. Agricultural and Resource Economics Review 35:155-166.

Holsten, E. H., R. A. Werner, and R. L. Develice. 1995. Effects of a spruce beetle (Coleoptera: Scolytidae) outbreak and fire on Lutz spruce in Alaska. Environmental Entomology 24:1539-1547.

Ives, A. R., and S. R. Carpenter. 2007. Stability and diversity of ecosystems. Science 317:58-62. http://dx.doi.org/10.1126/science.1133258

Johnstone, J. F., and F. S. Chapin III. 2006. Fire interval effects on successional trajectory in boreal forests of northwest Canada. Ecosystems 9:268-277. http://dx.doi.org/10.1007/s10021-005-0061-2

Johnstone, J. F., T. N. Hollingsworth, F. S. Chapin III, and M. C. Mack. 2010. Changes in fire regime break the legacy lock on successional trajectories in Alaskan boreal forest. Global Change Biology 16:1281-1295. http://dx.doi.org/10.1111/j.1365-2486.2009.02051. $\underline{\mathrm{x}}$

Kasischke, E. S., D. L. Verbyla, T. S. Rupp, A. D. McGuire, K. A. Murphy, R. Jandt, J. L. Barnes, E. E. Hoy, P. A. Duffy, M. Calef, et al. 2010. Alaska's changing fire regime - implications for the vulnerability of its boreal forests. Canadian Journal of Forest Research 40:1313-1324. http://dx.doi.org/10.1139/X10-098

Kenai National Wildlife Refuge Fire Management Staff. 2001. Kenai National Wildlife Refuge 2001 fire management plan. U.S. Fish and Wildlife Service, Soldotna, Alaska, U.S.A. [online] URL: http://www.fws.gov/fire/fmp/region7/alaska/kenai nwr.pdf
Kenai Peninsula Borough. 2012. Kenai Peninsula Borough home page. Kenai Peninsula Borough, Soldotna, Alaska, USA. [online] URL: http://www.borough.kenai.ak.us/

Kendrick, A. 2003. The flux of trust: caribou co-management in northern Canada. Environments 31:41-59.

Kofinas, G. P., F. S. Chapin III, S. BurnSilver, J. I. Schmidt, N. L. Fresco, K. Kielland, S. Martin, A. Springsteen, and T. S. Rupp. 2010. Resilience of Athabascan subsistence systems to interior Alaska's changing climate. Canadian Journal of Forest Research 40:1347-1359. http://dx. doi.org/10.1139/X10-108

Lieffers, V. J., S. E. Macdonald, and E. H. Hogg. 1993. Ecology of and control strategies for Calamagrostis canadensis in boreal forest sites. Canadian Journal of Forest Research 23:2070-2077. http://dx.doi.org/10.1139/x93-258

Liu, J., T. Dietz, S. R. Carpenter, C. Folke, M. Alberti, C. L. Redman, S. H. Schneider, E. Ostrom, A. N. Pell, and J. Lubchenco, et al. 2007. Coupled human and natural systems. AMBIO 36:639-649. http://dx.doi.org/10.1579/0044-7447(2007)36[639:CHANS] 2.0.CO;2

Loring, P. A., and C. Gerlach. 2010. Food security and conservation of Yukon River salmon: are we asking too much of the Yukon River? Sustainability 2:2965-2987. http://dx.doi. org/10.3390/su2092965

Loring, P. A., and S. C. Gerlach. 2009. Food, culture, and human health in Alaska: an integrative approach to food security. Environmental Science \& Policy 12:466-478. http://dx.doi. org/10.1016/j.envsci.2008.10.006

Lovecraft, A. L. 2007. Transnational environmental management: U.S.-Canadian institutions at the interlocal scale. American Review of Canadian Studies 37:218-245. http://dx.doi. org/10.1080/02722010709481856

Lubchenco, J., A. M. Olson, L. B. Brubaker, S. R. Carpenter, M. M. Holland, S. P. Hubbell, S. A. Levin, J. A. MacMahon, P. A. Matson, and J. M. Melillo, et al. 1991. The Sustainable Biosphere Initiative: an ecological research agenda. Ecology 72:371-412. http://dx.doi.org/10.2307/2937183

Magness, D. R., A. L. Lovecraft, and J. M. Morton. 2012. Factors influencing individual management preferences for facilitating adaptation to climate change within the National Wildlife Refuge System. Wildlife Society Bulletin 36:457-468. http://dx.doi. org/10.1002/wsb.156

Mann, D. H., T. S. Rupp, M. A. Olson, and P. A. Duffy. 2012. Is Alaska's boreal forest now crossing a major ecological threshold? Arctic, Antarctic, and Alpine Research 44:319-331. http://dx.doi. org/10.1657/1938-4246-44.3.319

Marcot, B. G., M. P. Thompson, M. C. Runge, F. R. Thompson, S. McNulty, D. Cleaves, M. Tomosy, L. A. Fisher, and A. Bliss. 2012. Recent advances in applying decision science to managing national forests. Forest Ecology and Management 285:123-132. http://dx.doi.org/10.1016/j.foreco.2012.08.024

Martinuzzi, S., V. C. Radeloff, J. V. Higgins, D. P. Helmers, A. J. Plantings, and and D. J. Lewis. 2013. Key areas for conserving United States' biodiversity likely threatened by future land use change. Ecosphere 4(5): 58. http://dx.doi.org/10.1890/ES12-00376.1 
McNeeley, S. M., and M. D. Shulski. 2011. Anatomy of a closing window: vulnerability to changing seasonality in interior Alaska. Global Environmental Change 21:464-473. http://dx.doi. org/10.1016/j.gloenvcha.2011.02.003

Mendelsohn, R., and S. Olmstead. 2009. The economic valuation of environmental amenities and disamenities: methods and applications. Annual Review of Environment and Resources 34:325-347. http://dx.doi.org/10.1146/annurev-environ-011509-135201

Millennium Ecosystem Assessment. 2005. Ecosystems and human well-being: biodiversity synthesis. World Resources Institute, Washington, D.C., USA. http://www.unep.org/maweb/documents/ document.354.aspx.pdf

Mooney, H., A. Larigauderie, M. Cesario, T. Elmquist, O. HoeghGuldberg, S. Lavorel, G. M. Mace, M. Palmer, R. Scholes, and T. Yahara. 2009. Biodiversity, climate change, and ecosystem services. Current Opinion in Environmental Sustainability 1:46-54. http://dx.doi.org/10.1016/j.cosust.2009.07.006

Morton, J. M., E. Berg, D. Newbould, D. MacLean, and L. O'Brien. 2006. Wilderness fire stewardship on the Kenai National Wildlife Refuge, Alaska. International Journal of Wilderness 12:14-17.

National Oceanic and Atmospheric Administration (NOAA) Fisheries. 2014. Chinook salmon bycatch management. Alaska Regional Office, National Marine Fisheries Service, Juneau, Alaska, USA. [online] URL: http://alaskafisheries.noaa.gov/ Sustainablefisheries/bycatch/default.htm

Olsson, P., Ö. Bodin, and C. Folke. 2010. Building transformative capacity for ecosystem stewardship in social-ecological systems. Pages 263-285 in D. Armitage and R. Plummer, editors. Adaptive capacity and environmental governance: Springer series on environmental management. Springer-Verlag, Berlin, Germany. http://dx.doi.org/10.1007/978-3-642-12194-4 13

Olsson, P., C. Folke, and T. Hahn. 2004. Social-ecological transformation for ecosystem management: the development of adaptive co-management of a wetland landscape in southern Sweden. Ecology and Society 9(4): 2. [online] URL: ttp://www. ecologyandsociety.org/vol9/iss4/art2/

Olsson, P., C. Folke, and T. P. Hughes. 2008. Navigating the transition to ecosystem-based management of the Great Barrier Reef, Australia. Proceedings of the National Academy of Sciences of the United States of America 105:9489-9494. http://dx.doi. org/10.1073/pnas.0706905105

Olsson, P., L. H. Gunderson, S. R. Carpenter, P. Ryan, L. Lebel, C. Folke, and C. S. Holling. 2006. Shooting the rapids: navigating transitions to adaptive governance of social-ecological systems. Ecology and Society 11(1): 18. [online] URL: http://www. ecologyandsociety.org/vol11/iss1/art18/

Ostrom, E. 2007. A diagnostic approach for going beyond panaceas. Proceedings of the National Academy of Sciences of the United States of America 104:15181-15187. http://dx.doi. org/10.1073/pnas.0702288104

Ostrom, E., and M. Cox. 2010. Moving beyond panaceas: a multitiered diagnostic approach for social-ecological analysis. Environmental Conservation 37:451-463. http://dx.doi.org/10.1017/ $\underline{\mathrm{S} 0376892910000834}$
Ostrom, E., M. A. Janssen, and J. M. Anderies. 2007. Going beyond panaceas. Proceedings of the National Academy of Sciences of the United States of America 104:15176-15178. http:// dx.doi.org/10.1073/pnas.0701886104

Polasky, S., S. R. Carpenter, C. Folke, and B. Keeler. 2011. Decision-making under great uncertainty: environmental management in an era of global change. Trends in Ecology \& Evolution 26:398-404. http://dx.doi.org/10.1016/j.tree.2011.04.007

Redman, C. L., J. M. Grove, and L. H. Kuby. 2004. Integrating social science into the Long-term Ecological Research (LTER) network: social dimensions of ecological change and ecological dimensions of social change. Ecosystems 7:161-171. http://dx. doi. org/10.1007/s10021-003-0215-Z

Rockström, J., W. Steffen, K. Noone, Å. Persson, F. S. Chapin III, E. Lambin, T. M. Lenton, M. Scheffer, C. Folke, H. Schellnhuber, et al. 2009. Planetary boundaries: exploring the safe operating space for humanity. Ecology and Society 14(2): 32. [online] URL: http://www.ecologyandsociety.org/vol14/iss2/art32

Ruckelshaus, M., T. Klinger, N. Knowlton, P. Douglas, and D. E. Master. 2008. Marine ecosystem-based management in practice: scientific and governance challenges. Bioscience 58:53-63. http:// dx.doi.org/10.1641/B580110

Scheffer, M. 2009. Critical transitions in nature and society. Princeton University Press, Princeton, New Jersey, USA.

Scheffer, M., S. Carpenter, J. A. Foley, C. Folke, and B. Walker. 2001. Catastrophic shifts in ecosystems. Nature 413:591-596. http://dx.doi.org/10.1038/35098000

Schulz, B. 1995. Changes over time in fuel-loading associated with spruce beetle-impacted stands of the Kenai Peninsula, Alaska. Forest Health Management Technical Report R10-TP-53. U.S. Forest Service, Anchorage, Alaska, USA.

Schulz, B. 2003. Changes in downed and dead woody material following a spruce beetle outbreak on the Kenai Peninsula, Alaska. U.S. Forest Service Research Paper PNW-RP-559. U.S. Forest Service, Anchorage, Alaska, USA.

Serreze, M. C., J. E. Walsh, T. Osterkamp, M. Dyurgerov, V. Romanovsky, W. C. Oechel, J. Morison, T. Zhang, and R. G. Barry. 2000. Observational evidence of recent change in the northern high-latitude environment. Climatic Change 46:159-207. http://dx.doi.org/10.1023/A:1005504031923

Sherriff, R. L., E. E. Berg, and A. E. Miller. 2011. Climate variability and spruce beetle (Dendroctonus rufipennis) outbreaks in south-central and southwest Alaska. Ecology 92:1459-1470. http://dx.doi.org/10.1890/10-1118.1

Smith, M. D., A. K. Knapp, and S. L. Collins. 2009. A framework for assessing ecosystem dynamics in response to chronic resource alterations induced by global change. Ecology 90:3279-3289. http://dx.doi.org/10.1890/08-1815.1

Stephens, S. L., J. K. Agee, P. Z. Fulé, M. P. North, W. H. Romme, T. W. Swetnam, and M. G. Turner. 2013. Managing forests and fire in changing climates. Science 342:41-42. http://dx.doi. org/10.1126/science. 1240294

Stram, D. L., and D. C. K. Evans. 2009. Fishery management responses to climate change in the North Pacific. ICES Journal 
of Marine Science 66:1633-1639. http://dx.doi.org/10.1093/ icesjms/fsp138

Trainor, S. F., M. Calef, D. Natcher, F. S. Chapin III, A. D. McGuire, O. Huntington, P. Duffy, T. S. Rupp, L. DeWilde, M. Kwart, et al. 2009. Vulnerability and adaptation to climate-related fire impacts in rural and urban interior Alaska. Polar Research 28:100-118. http://dx.doi.org/10.1111/j.1751-8369.2009.00101.x

Turner, M. G., D. C. Donato, and W. H. Romme. 2012. Consequences of spatial heterogeneity for ecosystem services in changing forest landscapes: priorities for future research. Landscape Ecology 28:1081-1097. http://dx.doi.org/10.1007/ $\underline{\text { s10980-012-9741-4 }}$

U.S. Census Bureau. 2014. Easy stats. U.S. Census Bureau, Washington, D.C., USA. [online] URL: http://www.census.gov/ easystats/

U.S. Fish \& Wildlife Service. 2010. Rising to the urgent challenge: strategic plan for responding to accelerating climate change. U.S. Fish \& Wildlife Service, Washington, D.C., USA. [online] URL: http://www.fws.gov/home/climatechange/pdf/ccstrategicplan.pdf

U.S. Forest Service. 2010. National roadmap for responding to climate change. U.S. Forest Service, Morgantown, West Virginia, USA. [online] URL: http://www.fs.fed.us/climatechange/pdf/ roadmap.pdf

Vitousek, P. M., H. A. Mooney, J. Lubchenco, and J. M. Melillo. 1997. Human domination of Earth's ecosystems. Science 277:494-499. http://dx.doi.org/10.1126/science.277.5325.494

Walker, B., S. Carpenter, J. Anderies, N. Abel, G. Cumming, M. Janssen, L. Lebel, J. Norberg, G. D. Peterson, and R. Pritchard. 2002. Resilience management in social-ecological systems: a working hypothesis for a participatory approach. Conservation Ecology 6(1):14. [online] URL: http://www.ecologyandsociety. org/vol6/iss1/art14

Walters, C. J., and C. S. Holling. 1990. Large-scale management experiments and learning by doing. Ecology 71:2060-2068. http:// dx.doi.org/10.2307/1938620

Weber, M. G., and M. D. Flannigan. 1997. Canadian boreal forest ecosystem structure and function in a changing climate: impact on fire regimes. Environmental Reviews 5:145-166. http://dx.doi. org/10.1139/a97-008

Weitzman, M. L. 1994. On the "environmental" discount rate. Journal of Environmental Economics and Management 26:200-209. http://dx.doi.org/10.1006/jeem.1994.1012

Werner, R. A., E. H. Holsten, S. M. Matsuoka, and R. E. Burnside. 2006. Spruce beetles and forest ecosystems in southcentral Alaska: a review of 30 years of research. Forest Ecology and Management 227:195-206. http://dx.doi.org/10.1016/j. foreco.2006.02.050

Westley, F., P. Olsson, C. Folke, T. Homer-Dixon, H. Vredenburg, D. Loorbach, J. Thompson, M. Nilsson, E. Lambin, and J. Sendzimir, et al. 2011. Tipping toward sustainability: emerging pathways of transformation. AMBIO 40:762-780. http://dx.doi. org/10.1007/s13280-011-0186-9
Wolfe, R. 2000. Subsistence in Alaska: a year 2000 update. Division of Subsistence, Alaska Department of Fish and Game, Juneau, Alaska, USA. [online]: URL: http://www.subsistence. adfg.state.ak.us/download/download/subupd00.pdf

Yin, R. K. 2009. Case study research: design and methods. Sage, Thousand Oaks, California, USA. 